\title{
NOTES ON THE GEOLOGY
}

OF THE

MONTICELLO AREA

VIRGINIA

By W. A. LAMBETH

A Thesis presented to the Faculty of the University of Virginia as a part of the requirements for the elegree of Doctor of Philosophy

JUNE 13TH, IgOI 

This petrographical study, under the direction of Professor Fontaine, was commenced in the fall of 1899 , with the object of determining whether the rocks of the Southwest Mountain were of igneous or sedimentary origin, and at the same time of defining their relations with the rocks east and west; but as the work progressed, it was found that no adequate conception could be obtained, or description given, without consideration of the bordering rocks. The area has, therefore, been extended west to the basal Archean and east to the Cambrian rocks, although the work done on these additions has been with much less detail. The territory is a virgin one, no work having been done upon it since the publication of Rogers' Virginia Reports, in 1835 , and his references to this section were passing and exceedingly general, so that without guidance from previous investigations, it is readily understood that the task has been no easy one. It is here acknowledged that the work is not as complete as would be desired, and yet it is believed to have progressed far enough to demonstrate the igneous character of the principal rocks in question.

It is obvious that a written description alone cannot be relied upon to picture the geography, or the rocks in their relations, so that use is made of a diagrammatic map, which accompanies and forms a part of this paper. The contour lines have been interpolated from the U. S. G. S., and while the map contains many inaccuracies, it represents the points of interest, topographical features and location of rocks in their exposures, so that, by its use, they may be easily found. The numbers in circles correspond with the numbers found on the collection of specimens, as well as upon those of which thin sections have been made.

The botanical work in the identification of species was, in the main, completed a year ago, and has been pursued further only so far as it was believed to be related to the geology of the section.

This paper, together with maps and rock specimens, is submitted as a part of the work required for the degree of Doctor of Philosophy in the University of Virginia. 


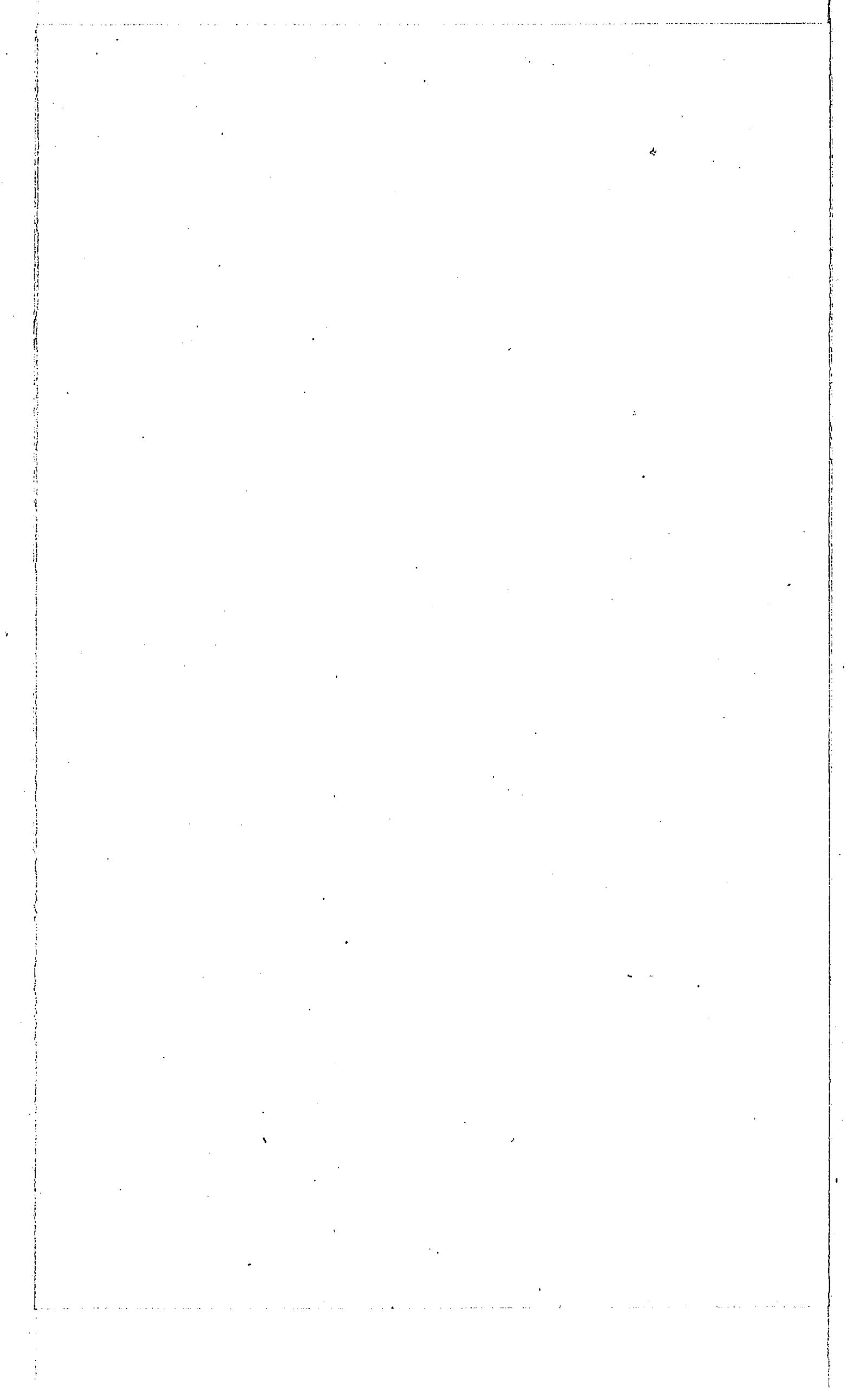




\section{GEOLOGY OF THE MONTICELLO AREA.}

The quadrangle embraced between latitudes N. $37^{\circ} 59^{\prime}$ on the south and N. $3^{\circ} 3^{\prime}$ on the north, and longitude W. $78^{\circ} 20^{\prime}$ on the east, and $75^{\circ} 30^{\prime}$ on the west, is sittated near the centre of the State of Virginia, and in the county of Albemarle. It contains about forty-five square miles, and has been named from Monticello, the home of Thomas Jefferson, as being its most distinguishing historic feature, though this old mansion is not in its immediate centre, but rather in its southwestern portion.

\section{TOPOGRAPHY.}

The area offers as its most characteristic topographic feature a section of Southwest Mountain. Southwest Mountain is the name proposed for the entire range, whose greater altitudes are known locally from southwest to northeast as Buffalo Ridge, Carter's Mountain, Monticello Mountain, Rich's Mountain, Randolph Mountain, Peter's Mountain and Clark's Mountain, respectively, although no part of Buffalo Ridge, Peter's or Clark's Mountain belongs to this area as defined above. The elevation above the mean sea level is from one hundred and ninety-five feet at the mouth of Carroll's Creek, near the eastern boundary, to twenty-one hundred feet on the crown of Carter's Mountain, in the mid-southern portion. The mountain chain is somewhat irregular, but in general maintains a constant southwest by northeast direction through the counties of Orange and Albemarle and along the adjoining borders of Nelson and Buckingham Counties. The irregularities in position and inecualities in altitudes have been cvolved in the course of irregular erosion consequent upon the clifference in the character of the rock material. There is no evidence that the tops of these mountains were originally higher than the surrounding country, but there is reason for believing that they formed only a part of a great plateau, for nowhere as yet has field observation disclosed on their tops or flanks any rock differing in essential characters from that forming the great masses in the body of the mountain. Regardless of the original source of this mass of rock matter, it has more than probably been elevated by movements in the crust of the earth, producing metamorphic conditions rendering the material unequally effective against erosion, and the intensity of this action being concentrated along fixed lines of force, has simulated the effects of mountain upheaval. With this interpretation, they may properly be classified and regarded as typical erosion mountains. The country west of these mountains forms a valley about twenty miles in width, which lies between the Blue Ridge and Southwest Mountains. Thus it is seen that the Southwest Mountain system pursues a course parallel with and about twenty 
miles east of the Blue Ridge. The portion of region shown in the Monticello Area to the west of the Southwest system is shaped, in the main, by the larger streams, which near their sources pursue a course parallel with the strike of the rocks, $i$. $e$., northeast by southwest. These streams have shaped the larger hills and ridges with their intervening valleys. From the flanks of the ridges smaller streams are sent as tributaries to the larger ones, chiseling the ridges into hills, longer or shorter, and these again into hillocks. When the streams have reached sufficient magnitude they cut their way to the east and empty their waters into the Rivanna River.

The Rivanna River courses obliquely and irregularly across the quadrangle, receiving its tributaries, which have a systematic arrangement. It has considerable volume and a speedy current, and is, therefore, at present busy cutting deeper its bed. As exposed now, it is younger than the mountain, for in its short course of nine miles in this area it has made two ineffectual attempts to cut its channel through them. In both, instances of failure it has been deflected southward in its course, until finding a softer point, it finally cut its way across the axis, making its escape to the southeast. The larger tributaries fall to the river from the north. These are Carroll's, Limestone and Mechtunck Creeks, all three situated east of the mountain, in the order named. There is evidence of the present drainage system having been developed upon an older one with entirely different features, the change having been in the nature of stream-capture; for standing upon the summit of Carter's Mountain, a point from which nearly every important feature of the quadrangle falls into view, it seems to the observer that Moore's Creek, now the principal tributary joining the Rivanna from the southwest, originally flowed parallel with the Rivanna, crossing the axis of the range just southwest of Carter's Mountain; but, owing to the more rapid cutting of the Rivanna, its base was finally low enough to attract the water from the more southwest stream, possibly through one of its tributaries. If such capture processes were frequent, and observation strengthens the idea, then it is easy to see that there must have been in some past time a reversal of water sheds and catchment basins. The streams then more than likely purstied in general a southwest course, with the strike of the strata and the flanks of the basins looking southeast and northwest, whereas now they flow across the strike, and their flanks look northeast and southwest.

\section{LITHOLOGY OF THE MONTICELLO AREA.}

To render a description of the rocks more orderly and intelligible for reasons hinted at the outset, a brief review of those to the west of the Monticello Area will be given. The principal and most conspicuous rock in that portion of the valley, immediately west of the Southwest Mountain, is a mica schist which exhibits all grades of texture in transition from a massive quartzose mica schist resembling a conglomerate, to a fine grained 
mica slate. The massive outcrops occur at very regular intervals from west to east, alternating with the softer and finer grained slates. They are resisting in their nature and have acted as a framework in lolding up the ridges, whereas, the slates being softer, weather more easily and have been cut away, forming the intervening valleys. This, combined with the dip of the beds, has resulted in hills whose northwest faces are invariably steeper, and in many cases precipitous, while their southeast slopes are gentle in their decline. Four such ridges traverse the city of Charlottesville in the direction of their strike, and upon them some of the principal residence streets are located, as in the case of Park and Ridge Streets. These mica schists differ very greatly in their accessory minerals as well as in texture. They are all rich in mica and especially muscovite. Biotite occurs, though, in a thin ledge crossing the area near Fry Springs to such an extent as to give the rock the appearance of an igneous mass. Free silica occurs. in the ledge running with the Willoughby road so conspicuously as to liave suggested the name of "Sandstone Ridge." Between these two extremes of nearly pure mica on one hand and nearly pure quartzose schist on the other, there are all transitional grades. In certain situations they become rich in feldspars; magnetite is quite common-in fact, occurs throughout in all the ledges, and especially near Still House Mountain, where it rivals the mica in abundance and has led to the belief that iron ore occurs in the mountain. A specimen of this magnetite will be found in the collection, as well as many varieties of the mica schists. Pyrite is another mineral occurring in these schists, though it seems even more prevalent in the slates, and especially in the dark variety. The slates do not differ essentially in mineral composition from the mica schists. They are finer grained, softer in character, and frequently blackened from contained graphitic matter. In their cleavage planes small cuboid cavities are seen, which represent spaces previously occupied by pyrite crystals, in which, when not empty, the crystal has been converted into limonite.

Striking with these beds there are two ledges that cross the territoryone just west of Sunny Side, near Still House Mountain, the other passing through the city of Charlottesville from the foot of Ridge Strect-that resemble conglomerates; in fact, the ledge crossing at Still House Mountain is referred to by Rogers as such by name. The matrix consists of fine quartz grains and scales of mica, enclosing quartz pebbles of all sizes up to two inches. Many of them are rounded as if water-worn; they have a bluish tint and a waxy lustre on fracture; the mass is lighly metamorphosed bluish tint and waxy lustre on fracture; the mass is highly metamorphosed and the pebbles may represent secondary results and not a true conglomerate. To the west of this system of schists and slates which is regarded as Huronian, and underlying it, is found the most eastern of the Archean outcrops of granite-gneiss. This is regarded as Archean because of its basal position and the absence of any charncter suggesting its poissible sedimentary origin. Moreover, the sediments to the east do not strike with the eastern margin of this granitic terrane by a difference of $\mathrm{I}^{\circ}$, thits establishing a nonconformity. This granitic-gneiss is intensely crystalline and generally massive; the minerals composing it are plagioclase and ortho- 
clase feldspar, some hornblende, quartz and biotite mica; further southwest toward Ragged Mountains hornblende replaces the biotite to some extent, forming a rock designated Hornblende by Rogers.

While crystallization is intense, the crystals show the effects of disturbance in the absence of clear-cut, well-defined crystals as are ustally found in igneous rocks of later age, as for instance, the porphyries and diorites that cut the Algonkian Rocks near by. A thin section of this rock exhibits the evidence of violence in a broken, confused and unnatural entanglement, displacement and distortion of crystals and fragments of crystals, due to repeated disturbance.

Igneous activity, both during and subsequent to the laying down of the Huronian sediments, is evidenced by beds of felsite which are contemporaneous with the sediments, perhaps representing water-worked dustfalls. There is a large porphyritic mass of doubtful age; it may be either contemporaneous or of later age. Also cutting the granitic terrane is found a single dyke of trap rock which clearly resembles diorite. The most conspicuous igneous mass in the Algonkian beds is a belt of diorite; generally about fourteen hundred feet across, outcropping at Fry's Spring, in the University grounds, and crossing the road leading from the University to Rio Station, on the Southern Railroad. This belt is also of doubtful age. The schists on the west of it and lying against it have been baked into a clinker-like darkened mass, while its eastern face is covered witl a bed of graphite slate. This suggests its contemporaneity and a surface flow, but in the excavations being made at the new Athletic Ficld for the University, it shows branching offshoots of a laccolitic character, with schists baked on both sides of the laccolite. In this same situation there is abundant evidence of disturbance in the confused intermixture of dioritic matter and mica slates. Thin belts of igneous rock of similar character occur scattered throughout the Algonkian beds. A dyke of gabbro is found in the suburbs of Charlottesville, near the Willoughby road, which has changed to an impure serpentine. Another of coarser texture, but purer and more completely changed, occurs near Sunny Side, north of the University. Mineralogically these gabbros are composed of olivine, biotite, mica and feldspar; in the subsequent change to form serpentine 'much of the feldspar has remained, and this, combined with a percentage of quartz, has rendered the rock too hard to be easily worked.

The dioritic rocks vary in character and composition even in the same belt. The structure is massive and marked by joint planes crossing each other at such angles as to give cuboidal blocks which weather into round boulders on the surface. Its richness in lime and soda is indicated by its rapid decay on exposure, resulting in a rusty red soil. The minerals are plagioclase feldspar, hornblende, biotite, mica and ptuartz. These minerals vary through wide limits, giving a quartz or mica diorite, anci in consequence their durability varies. They are universally massive, granitic in texture and dark in color.

The felsites and porphyries are mainly composed of orthoclase feldspar, though frequently with admixture of quartz. 
So far this description of rocks has related to those immediately west of the Monticello Area and in the walley situated between the Blue Ridge and Southwest Mountains. They are regarded as Huronian for reasons given further on. Now we come to those that touch the west boundary of the Monticello rocks-the rocks we set out to define in relation to their origin.

Historically, the only published investigations relating to these rocks was the passing reference by Rogers in his Virginia Reports in 1835 * $^{*} \mathrm{He}$ recognized the difficulty in defining them, but arrived finally at the conclusion that they were all sedimentary in origin, but having later been subjected to "igneous action." He says: "Looking merely at the mineralogical constitution of the rocks in many localities, an impression of the undoubted primary character of this district would naturally arise. But when a nore general exploration of the region discloses the existence of extensive beds of genuine sandstone and conglomerate rocks frequently in contact with the former, and having a uniform inclination, we are unable to longer maintain this view. $* * * *$ The crystalline appearing rocks are in reality modified forms of sandstone and conglomerate, which through intense igncous action have been made to assume appearances more or less resembling those of rocks of the crystalline class, thus disguising their original sedimentary structure." The rocks here referred to by Professor Rogers constitute more than half of the surface of the Monticello Area. For descriptive purposes they will be referred to in this paper as Monticello schists, for, notwithstanding the fact that much of the material is slaty, the prevailing and characteristic rock is schistose. The western boundary of these schists is indicated on the map, as well as its relation to the Huronian mica schists to the west, which have already been described. Beginning on the south, about two hundred yards west of Hartman's Mill, near the centre of the southern limits of the area, it follows very closely the Scottsville road into the city of Charlottesville, crossing the Chesapeake and Ohio Railroad one hundred yards west of the passenger depot or "Lower Station," thence in a northeasterly direction past the cemetery and east of Park Street, very nearly along the route pursued by the city main sewer, crossing the Rivanna River just north of Pent, Park. The western boundary line is observed to be a curving one, with its greatest convexity toward the west at a point opposite Judge White's residence, on Locust Strect, in the northeast portion of the city.

Using the term strike for its direction, this line is approximately $50^{\circ}$. N. E., although its most southern part is only $27^{\circ} \mathrm{N}$. E., and its most northern as much as $5^{\circ} \mathrm{N}$. E. The belt averages three and one-half miles, but, in some places, as just north of Monticello, it reaches four and onehalf miles in width. This junction is further marked by rock characters as you approach it from the Huronian side, where the mica schists and slates take on a greenish tint and the foliation and cleavage become confused. These mica schists grow richer and richer in epidote and crystals of pyrite, and exhibit veins of epidote fron one to three inches in thickness.

*Geology of the Virginias. 
This great development of epidote was doubtless due to the disturbance of the mica schists by the igneous mass being forced up through, against and over them, and to the inutual reactions between the feldspathic elements and the ferro-magnesian minerals. The junction is also marked by a continuous line of springs along. this boundary, by the pronounced crushing of the Monticello schists and confusion of the adjoining Huronian sediments. The eastern boundary, beginning at the south, passes three lundred yards east of Simeon, following the road leading from Simeon past Milton to Shadwell Station, thence between the road leading from Shadwell to Keswick and the Chesapeake and Ohio Railroad, which latter it crosses a little west of Keswick Depot. The rocks thus circunscribed constitute the principal stbject of this paper, which undertakes the demonstration of their igneous origin. To this end the following facts may serve: First, nonconformity is indicated by many features, such as the crushed condition of the adjoining mica schists, as well as the margins of the Monticello schists, which have been mentioned with some detail. Also, by the line of springs coinciding with this boundary, and the difference in strike of the Huronian mica schists, which is ionly $33^{\circ}$, and the curving "strike" of the Monticello schists of $50^{\circ}$. To this may be added the varying thickness of this Monticello schist belt, which varies from three and onehalf to four and one-half miles in width. Second, lithological character; the Monticello schists are universally crystalline and fine grained even when they become slaty. They are hard and break with a splintery fracture. The structure is marked by joint planes and quartz veins from the thickness of a hair to an inch or more. Occasionally crystals of lime carbonate are seen in the cavities, also veins of the same mineral. These, of course, are secondary, and brought about by the changes that the original rock has experienced. Hornblende occurs in flattened tabular crystals, scales of micaceous chlorite occur everywhere, and, together with a rich development of epidote, give the rocks a green color, ranging from a pea green where richest in epidote to a dark slate green where chlorite is more prevalent. At times they become conspictiously amygdaloidal-the amygdules having been changed to epidote, which, resisting atmospheric action, are brought into prominence by the weathering of the surrounding schistose material. Third, chemical constitution shows them to be closely related to, if not identical with, a diabasic magma, as is shown in the following analysis :

$$
\begin{aligned}
& \text { Si } \mathrm{O}_{2}, .45 .03 \\
& \mathrm{Fe}_{2} \mathrm{O}_{3} \ldots 14.99 \\
& \mathrm{Al}_{2} \mathrm{O}_{3} \ldots 16.42 \\
& \mathrm{CaO} \ldots 7.98 \\
& \mathrm{MgO} \text {. . 6.15 } \\
& \mathrm{Na}_{2} \mathrm{O} \quad \ldots \quad 2.74 \\
& \mathrm{~K}_{2} \mathrm{O} \ldots .84
\end{aligned}
$$

Covering portions of this basic rock is found a light green rock which, owing to the presence of flesh-colored quartz and a pinkish feldspar, may 
take a reddish tint, but these are generally overshadowed by the prevallence of epidote, there being no chlorite developed here. Structurally they are more massive than the dark green schists; they are seldom slaty, but tend to break into rectangular blocks, as can be seen at a quarry on top of Monticello Mountain: In, some situations it becomes almost pure silica, resembling somewhat in appearance Cambrian quartzite of the Blue Ridge, and the similarity is even more striking in chemical constituents. In texture they are porphyritic, with a fine matrix of quartz and orthoclase feldspar. When the quartz crystals become larger they take on somewhat the appearance of concretions, which, in a fresh fracture, resemble oölitic texture. Larger phenocrysts of quartz and feldspar are scattered throughout the mass. Some of the feldspar has decomposed into a clay powder, while many of the larger crystals have been converted into epidote. In some instances the center of the phenocryst remains a feldspar, while the circumference has changed to epidote. Crystals of epidote occur in the joint planes, sometimes acicular, or they may have a fibrous arrangement resembling asbestos. The quartz veins are of all sizes and intersect each other at all angles. The rock is hard from its richness in quartz and feldspar, and its toughness is greatly increased by the presence of the epidote. Chemical analysis of this rock shows it to be related to the Rhyolites.*

$$
\begin{aligned}
& \text { Si } \mathrm{O}_{2} . .8 \mathrm{I} .40 \\
& \mathrm{Al}_{2} \mathrm{O}_{3} \ldots 6.33 \\
& \mathrm{Fe}_{2} \mathrm{O}_{3} \text {.. I.I8 } \\
& \mathrm{Na}_{2} \mathrm{O} \quad \ldots \quad .64 \\
& \mathrm{Ca} \mathrm{O} \text {.. trace. } \\
& \mathrm{Mg} \mathrm{O} \text {.. undetermined. } \\
& \mathrm{K}_{2} \mathrm{O} \text {.. 5.18 }
\end{aligned}
$$

To distinguish this acidic group of rocks from the Monticello schists, which are basic, the term Monticello Rhyolites will be used. The situations of these rocks have been indicated on the map in three positions in the midst of the Monticello schists, but since making the drawing closer observation has demonstrated a connection between these and a lateral expansion as well, so that in amount and importance they exceed by far the amounts there indicated. They exhibit the cliaracters of an igneous rock much more perfectly than the clarker sclists. They are possibly devitrified rhyolites, their porphyritic character being secondary upon an original glass, and may, therefore, under the term as suggested by Miss Bascom, be appropriately designated aporhyolites.

Beside these two classes of igneous rocks there appears what may be regarded as a single dyke of quartz porphyry. Its high percentage of silica suggests that it may be only the last segregated portion of the original magma-the last to cool and solidify. It is only twenty feet thick and surrounded by the Monticello schists on the cast side of the crest of Monticello Mountain. Analysis of this rock shows over ninety per cent. of silica. Another interesting feature is the presence of a persistent trace of cobalt.

*Analysis by R. E. Stallings. 


$$
\begin{array}{lrr}
\mathrm{Si} \mathrm{O}_{2} \ldots 93: 65 \\
\mathrm{Al}_{2} \mathrm{O}_{3} \ldots & 2.77 \\
\mathrm{Fe}_{2} \mathrm{O}_{3} \ldots & .78 \\
\mathrm{Na}_{2} \mathrm{O} \ldots & .68 \\
\mathrm{~K}_{2} \mathrm{O} & \ldots & .7 .74 \\
\text { Cobalt.. } & \text { trace }
\end{array}
$$

So far, then, chemical constitution would indicate their probable igneous origin; at least, it is compatible with the proposition. So also the textural and structural features here mentioned.

The Monticello schists are softer and have yiclded more readily and thoroughly to the infitence of metamorphism and subsequent erosion, and, in consequence, they are more frequently slaty, and have been worn away more rapidly, so that now they occur as the flanks of Southwest Mountain, while the more massive porplyyritic rocks are found at the top. As before indicated, these schists frequently exhibit a massive condition, but never retain, if they ever possessed, a coarscly crystalline texture. .

With the exception of the dyke of quartz porphyry these igneous masses have the characters of surface flows. This is indicated by the greater contact effects displayed at their western boundary; where there was a crushing and crumpling up of the mass, and perhaps a sliding to the west, as has been indicated. The crushing force shattered the schists into cubical fragments a fraction of an inch or more in diameter, and these have been stbsequently cemented together by a deposit of epidote. The conditions producing and spreading the cement carricd it into the mica schists, beyond where rocks clearly sedimentary in origin grow richer and richer in this deposit until the junction is reached. To these evidences will be subsequently acled those of soil and regetation, and while no single one may be sufficient, the combination seems to render a sedimentary origin extremely improhable, if not impossible. T'o sum up the evidences indicating the igneous origin of these mountain masses:

I. Entire absence of intercalated beds of undoubted sedimentary origin anywhere on the tops or sides of Southwest Mountain.

2. No transition can be found leading from undoubted sediments to .crystalline schists, but contact boundaries sharply defined exist between them throughout their western junction.

3. Nonconformity in strike of the Fturonian sediments with the western margin of the Monticello schists, and marlied cvidence of disturbance by contact effects in crushing and changes in the minerals, together with evidence of sliding to the west and the existence of the line of springs.

4. Lithological characters in the intensity of the metamorphism in the Monticello schists and slates as compared with the neighboring Huronian member.

5. Mineralogical, in that the minerals are those characteristically found in metamorphosed igneous rocks. The amygdaloidal features, as well as porphyritic textures, along with frequent masșive structures, may be mentioned here. 
6. Chemical analysis of the two types of these mountain rocks show their strong relationship with known rhyolites and diabases.

To these will later be added indication from the nature of the soil and distribution of vegetation.

\section{CAMBRIAN.}

The surface rocks of the southenst corner of the triangle, with the exception of a few thin dykes of dioritic rock, are sedimentary, and regarded as Cambrian for reasons given further on. They consist of conglomerates, coarse sandstone, slates and limestones.

\section{CONGLOMERATE.}

A conglomerate, constant in its relations, is found lying upon the eastern margin of the Monticello schists. At times it narrows down or is replaced by a course sandstone, but without destroying the continuity of the strata. The bed passes diagonally across the area, following the eastern flank of the Monticello schists. The contact is not always well defined, for the reason that in this situation there is frequently a system of slates which are not easily placed, either as Monticello schists which have been sheared into fissilc slates, or metantorphosed Huronian sediments. They doubtless take their origin from both sourees. The slates are generally a light shade of green, but owing to the oxidation of contained iron they are frequently red. The conglomerate bed is as much as a thousand feet thick in some exposures, but is frequently much narrower. The matrix consists of fine grains of sand, with occasional layers of clay. The sand particles frequently coalesce, forming a quartzite-matrix. The pebbles are of three varietiesquartz pebbles from the size of a. pea to a hazel nut, and both acidic and basic igneous fragments. Those derived from the basic rocks are the first to decay, leaving a rusty cavity, partially filled with silica and clay. Those derived from the acid igncous rocks, or the rhyolites, are better preserved, but of smaller size, while the quart\% conglomerate is well preserved and forms a most intractable rock. Some of the rhyolite pebbles are three inches long and one and one-half inches thick. They are characteristically spindle-shaped, and from their frecuent parallel arrangement at first sight suggest a fossiliferous origin. This phenomenon has been produced by the movements which rendered the matrix schistose and indurated. The smaller quartz pebbles do not present this appearance, having no order of arrangement, but seemingly deposited at random and left remaining.

Near Sineon the conglomerate is least resisting and contains less quartz, while near Dr. Bowcock's it is rich in quart\% and very firm. Another feature of interest is that, where the pebbles are mainly quartz the conglomerate bed is thinnest and increases in thickness as it grows richer in igneous rock fragments. 


\section{MICA SLATES.}

The term mica-slate is intended to include all the group of rocks which lie east of the Monticello schists, other than conglomerates, sandstones and limestones. They represent a mixed group of rocks, consisting of argillites, schists and slates; yet none of these terms fittingly define them. They are more or less crystalline, yet very slaty, tender and friable, decomposing rapidly at all outcrops. They are all rich in mich, occurring in large flakes, making a true mica slate, as well as fine scales in sericite. They are crumpled and disturbed, sometimes bent at right angles, and crinkled surfaces are common. In extent they cover an area about three miles in width, being cut in two places by diorite dykes and separated into an eastern and western belt by a ledge ò roofing slate. The limestone to be presently described is interbedded with the eastern beit. Quartz veins occur in great numbers, resembling true fissure veins, but very thin. Two of these are found to carry gold, and many others have been "prospected," but the amount of this metal so far observed is insufficient to warrant its cxtraction.

The principal slate ledge to be considered is that approximating a roofing slate. It has been quarried for this purpose at Forrest Hill and at a quarry about one mile east of Dr. Bowcock's. 'The bed is about seven or eight hundred feet thick, and although too soft for building purposes in its northern portion, some slate of fair quality has been quarried in its southern extension. The ledge passes Forest Hill, then west of the County. Alms House, crossing the Chesapeake and Ohio Railroad about one-half mile east of Keswick Depot. It is distinct and well marked in its course, showing on the surface at every abrasion. Its differentiated color and constant character have made it useful in exploring the territory and in the collection of specimens.

\section{MECHUNCK LIMESTONE.}

These beds are mentioned by Rogers, and he describes their peculiar mode of occurrence. They are interbedded with the mica slates, and the one occurring in this area represents a single link in a chain of similar beds occupying a similar position in relation to the axis of Southwest Mountain. They vary in thicliness and physical condition, the bed here showing no crystallization, while one of this chain near Lynchburg has been worked for marble. This bed seems to be wrapped up in the mica slates; still there is little doubt but that they are all parts of the same strata deposited contemporaneously, but in situations of deeper water. They are generally schistose or slaty, with seams filled with calcite. Outcrops retain the appearances of layering under water, which become more distinct in weathering.

Professor Rogers drew attention to the purity, abundance and accessibility of these rocks and their economic value. Especially did he urge their use in agriculture. Several kilns have been burned, but from causes which could not be discovered. The practice has ceased. The wisclom of Rogers' aclvice is verified by the use of this lime on the farm of Mr. Purvis, 
which, with its evidence of prosperity, contrnsts somewhat with other farms in the vicinity which have not been so treated. Some analyses, without intentionally selecting calcite veins, have proven to be as high as 96 per cent. in pure calciuni carbonate. Analysis of an average specimen gives the following:

$$
\begin{aligned}
& \text { Ca } \mathrm{CO}_{3} \text {..So.I } 3 \\
& \mathrm{Mg} \quad \mathrm{O} \ldots \mathrm{I} . \mathrm{Sg} \\
& \begin{array}{llll}
\mathrm{Fe}_{2} & \mathrm{O}_{3} \ldots & \mathrm{I}_{\mathrm{S}} \mathrm{S}_{5}
\end{array} \\
& \text { Si } \mathrm{O}_{2} \ldots 13.28
\end{aligned}
$$

The rocks eist of the limestone closely resemble those on the west already described. They are here even more tender and friable, and with somewhat more conspicuous quartz veins.

\section{SOIL.}

Two types of soil are represented in the area, both being well defined by constant characters sharply differentiated and of such visual prominence that even a casual observer must become cognizant of their differences. That of the southwestern section is light in color, running through gray shades to darker slate colors; it is siliceous and very micaceous, having little plasticity. The surface is clotted with fragments of quartz. which have been loosened by weathering from their connection with veins and segregations which have been deposited in the overturned strata. This soil has little production or agricultural strength, though it reacts rapidly under improvement and lias the advantage of being easily cultivated. Owing to its lack of plastic colerence it is easily cut by surface drainage where unprotected by vegetation.

The soil of the western and northwestern part of the area is darker in color and more fertile; the tints always have a reddish character. the predominant color being chocolate red; near the crest of the cultivated hills it becomes lemon color from the further oxidation of the iron, but shacles into richer reds as you descend to the valleys. The red tints come from the decay of ferro-magnesian minerals, a conspicuous element in the composition of the rocks forming the underlying strata. It doubtless derives its fertility from the decomposition of the rocks, which have a high percentage of lime and a tenth per cent. of phosphoric acid. From whatever source its fertility comes it is a common one, for the farms northwest of the road leading from Simeon througl Milton, Shadwell and on to Keswick, and situated on the red soils, are noted for their prosperity. This road happens to follow very closely the line separating the red and. gray soils; so closely, in fact, that it has caused the outgrowth of a common saying amongst the farmers of the section that you should never purchase a farm east of that road. The gray soil is a product of the decomposition of the mica slates, poor in lime and containing no phosphoric acid; it loses its fertility rapidly in cultivation, and will gain but little strength in lying fallow. On the other hand, the basis of the red soil is the Monticello schist and invites cultivation. The hastened decay liberates the elements seem- 
ingly needed for plant growth, and hence the land improves under cultivation. Although the contours of the red soil territory favor more rapid erosion and washing, they are nevertheless more stable, holding their position by their coherence and argillaceous character. They are more difficult to prepare for seeding, being what is termed "heavy," and require greater force to pulverize. This red belt passes from southwest to northeast, embracing some of the most prosperous farming lands in Albemarle County, and a circumscribing line defining these from all other soils follows accurately the boundaries already mentioned as those of the Monticello schists, thus furnishing another fact showing a different, if not an igneous, origin for these rocks.

\section{VEGETATION.}

As with the soils, so with the vegetation, there being a distinct vegetation produced by each soil; therefore, it is of geological importance. The forests of the red soil area are grander, the trees are taller and their trunks are longer, and where primeval few conifers appear, but a predominance of castanea, quercus alba and quercus rubra-in other words, a markedly deciduous flora. In the eastern gray soil section it is decidedly coniferous, consisting of some pinus rigida and much pinus taeda, together with many junipers. Considered altogether and aside from any geological relations, the flora is varied and interesting; perhaps such narrow limits do not, elsewhere in Albenarle County, enclose anything like its wide range of variety and perfection of species. While in no sense has the plant life been exhaustively studied, sufficient work has been done to warrant the inclusion of a summary in this paper, in order to add further cvidence of the igneous origin of the Monticello schists.

The running catalogue, given in a foot note, does not attempt to include all varieties, species or even families present, but a mere outline of representatives of those, whose flowers or foliage have attracted attention, either by their prominence, peculiarity of occurrence or geological importance.

Of the dicotyledonous angiosperms, twenty-six families have been identified, but for geological considerations they may be clisregarded with tew exceptions. The Quercus. Castanea, Sapinclaceae and Platanaceac families may be taken as the principal representatives of this class.*

Of the dicotyledenous gymnosperms, both cedars and pines occur in abundance, but especially Pinus taeda (old field pines).

In flowerless plants or acrogens, the richness in varietics of filices is noticeable. $t$

*Ranunculacene-anemone aquilegia; Anonacene, common pawpaw; Rapeveraceac, blood root and its related cruciform poppy; Vinlaceac, pedata and palmata: Caryophyllacene, two wild pinks and a cockle; Geraniacene, cranesbill and oxalis; Sapindacene lacene, two wild pinks and a cockle; Geraniacene, cranesbill and oxalis; Safnindacene in three maples; Anlacardiacene in sumac and poison ivy; Legummosie, scoparius, false indigo and locusts; Cornacene; Caprifoliacene; Rubiacene; Campanulaceae; Orchidacene Scrophulariacente; Lauraceae; Loranthaceat; Urticaceac; Plaetimaceat in sycimore; Cupuliferae in the alder; Quercus stellatn (post onk): Quercus lyrata (sessile onk); Quercus rubra (red oak); Quercus tinctoria (black oak); Quercus nigra (black jack); Quercus imbricata
(Spanish onk); Castanea Sativa (chestnut). Cyperaceae and Grnminae in profusion.

trn ferns there are two polypodia, two adianta, one pteris, four aspienia, two phegopteris, three aspidia, one onoclea and three osmundae. Ophioglossacene find representatives in Botrychium ternatum and B. Virginianum, Lycopodinceae dendroidium. In Jungermanniacene and Marchintiaceae there is a richness eclual to and in keeping with that of the higher orders. 
In a recent paper Mr. Hollick has shown the relationship between geological formations and forestry in New Jersey.* He demonstrates the presence of a southeastern coniferous zone, characterized by a predominant, though not exclusive, coniferous flora, and a northwestern deciduous zone. Between the two is a more or less fluctuating zone, which he terms the tension zone. Within the limits of either the deciduous or coniferous zones the conditions are practically uniform, the species having become fixed in the environment favorable to them, and the struggle for existence is only between individuals of the same species. In the tension zone the conditions are different, however, for there the struggle is not confined to individuals of the same species, but extends to that between different species. In consequence, there is always, a fluctuation of vegetation in the tension zone and accompanying elasticity in its boundaries. Facts so general cannot be gathered in the Monticello Area; consequently, conclusions must be less comprehensive. Still, in a general way, the same principle of relation between geological formation and plant distribution is illustrated. In the New Jersey district, the coniferous flora corresponds to and is situlated upon a particular rock formation; in the same manner the deciduous flora is confined to a different formation, while the tension zone flora, a mixture and overlapping of the two, corresponds to the junction of the two different geological formations.

By reference to the accompanying map it will be observed that the greater part corresponds in situation to the rocks supposed to be of igneous origin. Upon this part of the area rests the rich red fertile soils made from the disintegration of these rocks, and corresponds to Mr. Hollick's deciduous zone, for here this great group of plants have established themselves to the almost total exclusion of the conifer. In clearings in the natural forest there is frequently a temporary establishment of conifers, but nowhere upon this portion, where the struggle has been left unaffected by artificial conditions through thic aid of man, has there been a permanent fixation of these plants. Numerical data cannot be given, nor would stch data be adequate to demonstrate in a paper the impressions made tupon the obscrver in passing from this territory eastward into the coniferous zone. For, unlike the New Jersey territory, the sole difference, and indeed the greater difference, is not the presence or absence of species from one or the other parts of the area, but the different development of individuals of the same species in the different situations. For instance, it is not possible to draw a line anywhere which will separate all the conifers into onc, and all the decidious plants into another area; yet in no case need the observer hesitate to say that he is in the midst of one or the other zones; he would not be forced to tabulate or compare percentages of occurrence; but simply observe the development of individuals. Even the coloring of natural objects varies-the lichenis thenıelves seem grayer in the coniferous zoñe, as if in sympathy with their soil surroundings. Such then is the contrast within a few hundred yards that even an inexperienced observer would

*Annual Report of the State Geologist of New Jersey, 1899 . 
recognize, from the vegetation alone, that he is surrounded by a different set of conditions.

To be more specific a characteristic species may be selected from each territory. White oak (Quercus alba) may be taken as a representative of the deciduous area, and old ficld pine (Pinus tada) to represent the coniferous area. White oak attains its better developments in the central parts of the red soil area both in numbers and perfection of individuals, but more especially as to the latter, though they are found throughout both areas. Old field pine is the characteristic tree of the gray soil, though locally it may invade the red soil a few hundred yards, and at few indivicluals are dotted over the surface as if by accident.

To represent these impressions use may be macle of a chart in which Quercus stellata is used instead of Quercus alba, becaluse this tree was more specifically the object of observation, though it would probably represent the white oak equally as well. It will be noticed that the oak passes through both areas, but is less abundant in the coniferous area than in the deciduous, and very much less abundant than Pints treda. Pintus treda is very abundant in the coniferous zone, and extends but a very short distance into the deciduous zone, terminating almost abruptly with the linits of the coniferous area.

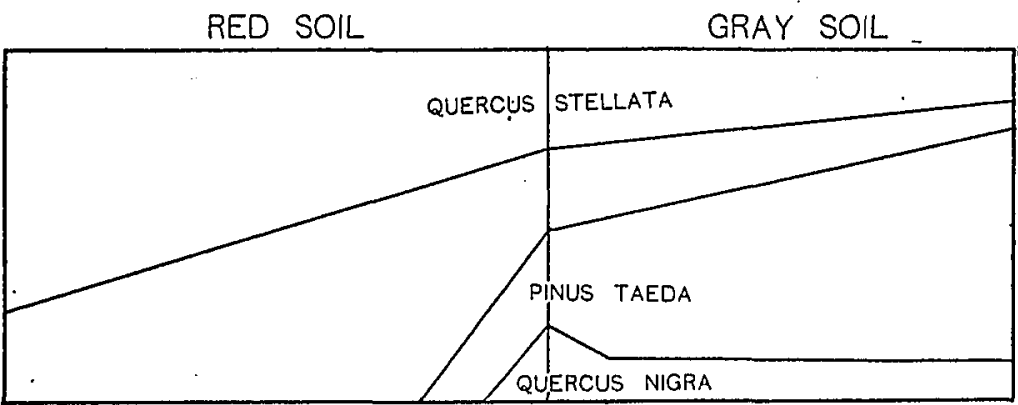

Quercus nigra (Black" Jack) is included in the chart because of its seeming relationship with what may be compared to Hollick's tension zone. It is more characteristic of the coniferous zone than of the decidtrous, though far less abundant here than the old field pine. It reaches: its greatest development in number and individuals in the tension zone, and is rarely found far in the deciduous zone.

Here then are variations in plant distribution that camnot be explained by difference in climate, meteorologic or physiographic conditions. For in a radius of a few miles in the same altitudes, there is equality of rain fall and similar relation to sun light-in fact, so far as can be observed, all the conditions usually considered as important in effecting clistribution apply with equal force to both situations. It seems intelligible then, only as due to the soil, and through this to the geological formation upon which it rests. 
Plant distribution, then, in the Monticello Area, as far as the evidence is valid at all, points to a different origin of the two rocks systems, and, therefore, cannot, as has been previously stated, represent modified portions of the sandstone and conglomerates which lie along their eastern border.

\section{ECONOMIC PRODUCTS.}

In the description of the rocks incidental reference has been made to materials that suggested industrial or economic valtue. To make such a list orderly, special mention of those previously considered may now be made with a few additions.

As to the metals, no indications point to their existence here in quantities sufficient to pay for their extraction. The residents in the vicinity of Still House Mountain belicve that a deposit of iron exists there. The heavy bedded mica schists are rich in crystals of magnetic iron, giving a high specific gravity to the rock which has led to this belief, but nothing indicating an ore deposit is present. Gold "streaks" have been obtained from panning selected specimens of quartz from the veins in the mica slates east of Sotuthwest Mountain, but the veins are thin and irregular in thickness, and of sucli general nature as to be uninviting to the prospector. Clilorite schists or deposits in them have been worked for copper south of this district, but no trace of this metal has been found here.

Building stone has been taken from the beds of massive mica schists, and when free from pyrite are durable, handsome and tool easily. The porphyry near Sunny Side is of a beautiful pink or red tint, but so far no specimen has been obtained from sufficient depth; that seen on the surface has weathered considerably, and the large phenocrysts have decayed. If however, it were opened up at some depth, a stone of great beauty and susceptible of polish could doubtless be obtained. A large specimen planed down, but unpolished, can be seen in the accompanying collection. Either of the two dykes of gabbro furnish serpentine, though it is rather too rich in quartz to be economically worked. The narrow intrușion of quartz porphyry on top of Monticello is valuable as a most durable road metal. The schist used for this purpose from the Moore Creek quarry is too soft and decays rapidly, whereas the quartz porphyry is not only intensely hard, being 93 per cent. quartz, with a durable feldspar, but its resistance to friction is greatly increased by the presence of epidote.

Limestones that occur so abundantly of marked purity and of easy access suggest their use both in building and in agriculture.

The mica slates are quarried for roofing purposes at Forest Hill and near Dr. Bowcock's. They are quarried for slate pencil at Cox quarry, just south of the area.

It is beyond the scope of this paper to attempt either a rock system or time classification of the rocks described in this area; nor is it in accordance with the conservatism characterizing the science of geology to group facts hurriedly without due consideration of the contiguous relations. Before a definite classification can be made the rocks both east and west of the area must be studied and charted in detail. Moreover, in dis- 
tricts like this one of certainly ancient gcological age, displaying such conspictrous and universal evidence of intense metamorphic disturbances, destroying all trace of its original conditions with complete destruction of all evidence of life so far as known, it is extremely hazardous to project a classification without encumbering it with so many reservations and provisions as to render final conclusions of questionable valuc.

However, as a suggestion to such as may prosecute further the work, the following provisional scheme is offered, together with such evidence as may not be conclusive, yet scems to conform to the facts and point at least in the direction of the truth.

- The column appears to be as follows: The base is Archean and lies to the west. It ascends as yon pass to the east over the rocks indicated in order from below upward:

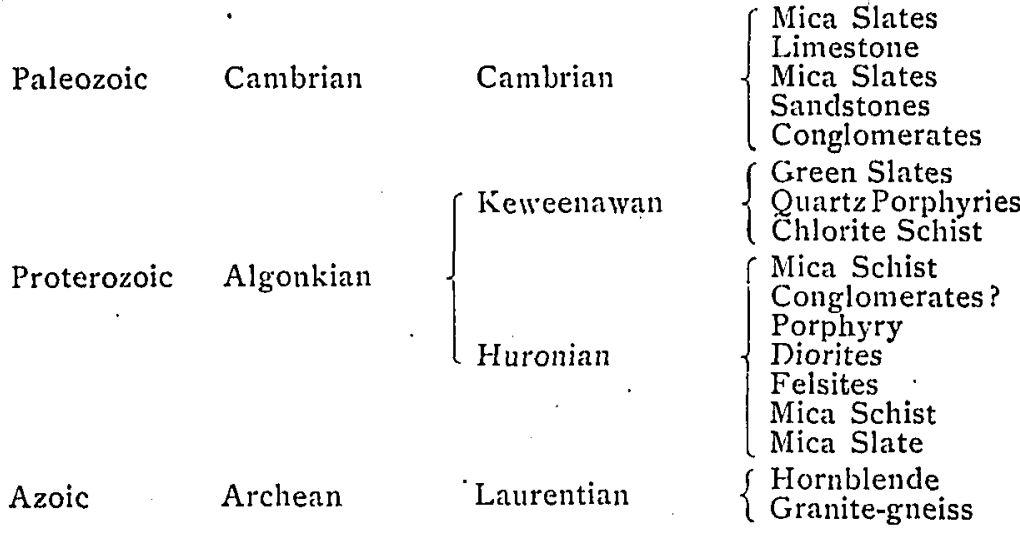

The following is the evidence for this grouping:

On traversing the valley between the Blue Ridge and Southwest Mountain two outcrops of massive rocks are seen, having the lithological characters of Archean granite gneiss. The second or most easterly one has been referred to and its character discussed, and for reasons there given it is selected as the base of a geological column for this region. The Archean origin of this mass has never been questioned, and, judged upon texture or structure, nothing suggests a doubt as to its position, for it has no character which indicates that it was ever sedimentary. Moreover, it lies beneath all other rocks, forming the base on which rests the Algonkian sediments.

Covering the eastern face of this terrane is found a wide stretch of mica slates and schists, which are very easily recognized as sediments which have been overturned and thrust up against the massive granitic mass. Owing to the difference in the direction of the eastern border of the terrane and the strike of the adjacent sediments, nonconformity is suggested. However, under the principle suggested by Van Hise, no such nonconformity is required to separate the Algonkian from the Archean, but that the one gives evidence of its sedimental origin and the other does not, is 
sufficient grounds for separation. The Huronian* slates alternate regularly with beds of coarse and massive mica schists-this condition continuing through what may be regarded as a Huronian series without interruption, except where cut or interlaminated with igneous dykes or layers. If these strata are regarded as reduplication from foldings, measured from centre to centre of the bed of massive mica schist, it would indicate a thickness of two or three thousand feet. No accurate statements can be given, however, but they certainly represent beds of vast depth. The beds dip at an angle of $52^{\circ} \mathrm{S}$. E., and represent closed and overturned folds.

The regularity in the alternation of beds of mica schist with mica slate is disturbed at one point by the great diorite belt which passes throngh them. It is difficult to decide whether this mass is contemporaneous or subsecutently intruded, for, as before stated, the data are uncertain. If intruded, it would seem that the rocks should show the same effects of baking on both sides of the belt, whereas this phenomenon is apparent only on the west face. If of stibsequent age the disturbance of the regular recurrence is explained. If a surface flow, as inclicated by the contact effects to the west and the graphite bed on the east, a nonconformity is here presented. But such intrusion due to igneous outflow, although dividing the Huronian rocks into two nearly equal halves, does not indicate orographic movement or separate one system from the other in time.

Referring to these questionable nonconformities excuse must be offered for their indefinite character. The detection of nonconformity in undisturbed regions is a comparatively simple process, but in Huronian strata more often than otherwise the later made sediments have again been folded, producing secondary texture and structure corresponding and coinciding with the structure and texture of the older sediments, or producing a tertiary texture and structure in the older, coinciding with the secondary structure and texture of the newer sediments, thus making a nonconformity appear a perfect conformity, regardless of the time separating their origin.

In this paper the rocks described as the Monticello schists, Monticello rhyolites and quartz porphyries will be regarded as representing the Keweenawan member of the Lake Superior region. Attention has already been directed to the zone of disturbance which marks the junction of these rocks with the Huronian schists on the west. Lithologically these rocks resemble those of Lalic Superior. Still more do they resemble those of South Mountain, Pennsylvania, though they lack those conclusive evidences such as bombs and breccia. Chemical analysis and the presence of amygdules, along with the general lithological and igneous characters, suggest a close similarity with the basic igneous rocks of Lake Superior. Notwithstanding this fact. Miss Bascom clid not regard the cridence as sufficient for 'correlation, although it was more conclusive than that exhibited in this area. To this may be added that search so far has failed to reveal any copper in this region, though it occurs and has been mined in the same system of rocks both north and south of the Monticello Area.

*These sediments are regarded as Huronian since they follow next after and upon the Archean, are always crystalline and have the general characters of the Huronian of the Lake Superior region. 
The mass of Southwest Mountain then is regarded as Keweenawan. The Monticello schists have been derived from a surface flow of diabasic magma filling a depression in Huronian rocks, with a schistose structure developed by later dynamic changes. At various places on the.surface of this magma there were later outpours, or cutting through it there were dykes of acidic or rhyolitic magmas, and these have formed the rocks described as Monticello Rhyolites and Quartz Porphyries. During Cambrian time erosion carried pebbles of both these rocks into the margin of the Eastern Cambrian Sea, where they lodged, forming the basal Cambrian conglomerate.

. The eastern limits of these Keweenawan rocks are covered by a great conglomerate, which may, as previously indicated, be separated from them by the interposition of a thin ledge of green slates, which are to, be regarded as modified Huronian sediments affected by the schists. This basal conglomerate is regarded as Cambrian, althougin it contains no fossils. Nothing suggests a missing member, and it has every character of a younger age than the Algonkian-for here we find the first true sandstone lying upon a basal conglonerate. A description of the succession of rocks as you pass west from the axis of the Blue Ridge in recognized Cambrian, strikingly resembles a like description as you pass east from the Monticello schists described in this paper. That the series discussed may belong to later times and younger rock systems is of course possible, but without the aid of paleontological evidence it cannot be placed otherwise than as here indicated.

Acknowledgment is made of the dangers of correlation purely upon lithological grounds; yet where no other method is available, though it may be in error, it is still an advance upon no beginning at all

The Cambrian, then, beginning with the conglomerates, must be extended to include the limestone and mica slates described in the Monticello Area. If they are Cambrian and synchronous with those west of the Blue Ridge, it is plain that during Cambrian time the truncated ends of these strata'pointing toward its axis were connected by intervening strata, although doubtless interrupted here and there by islands of Archean or Algonkian rocks. This series would then have covered much of the preexisting Algonkian, and have been subsequently removed by erosion from the higher points, leaving Cambrian deposits only in favorable situations by the pinching in or closing up of a fold. If at some future time Cambrian rocks are found east of the Southwest Mountain, no other conclusion seems possible. 


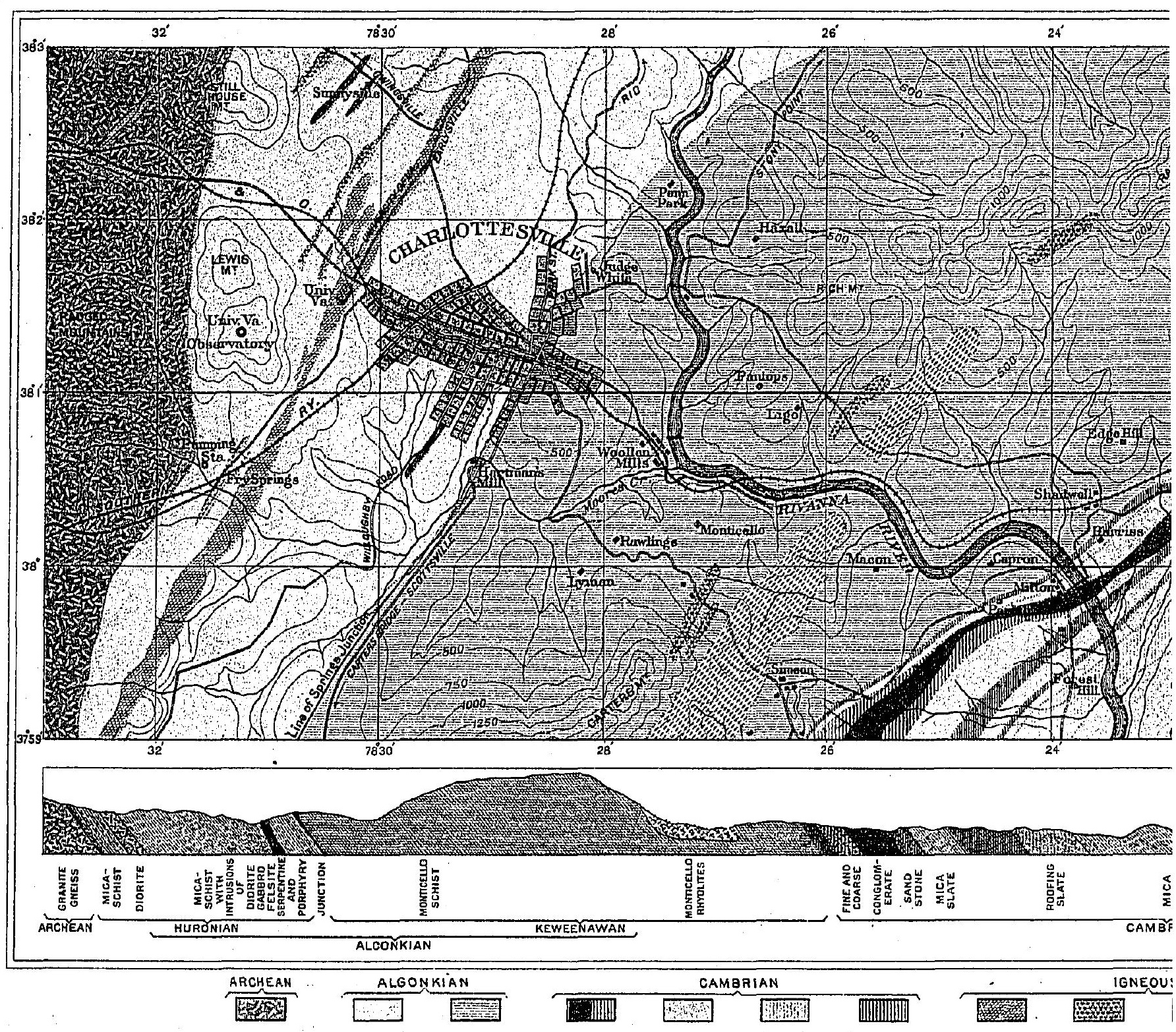




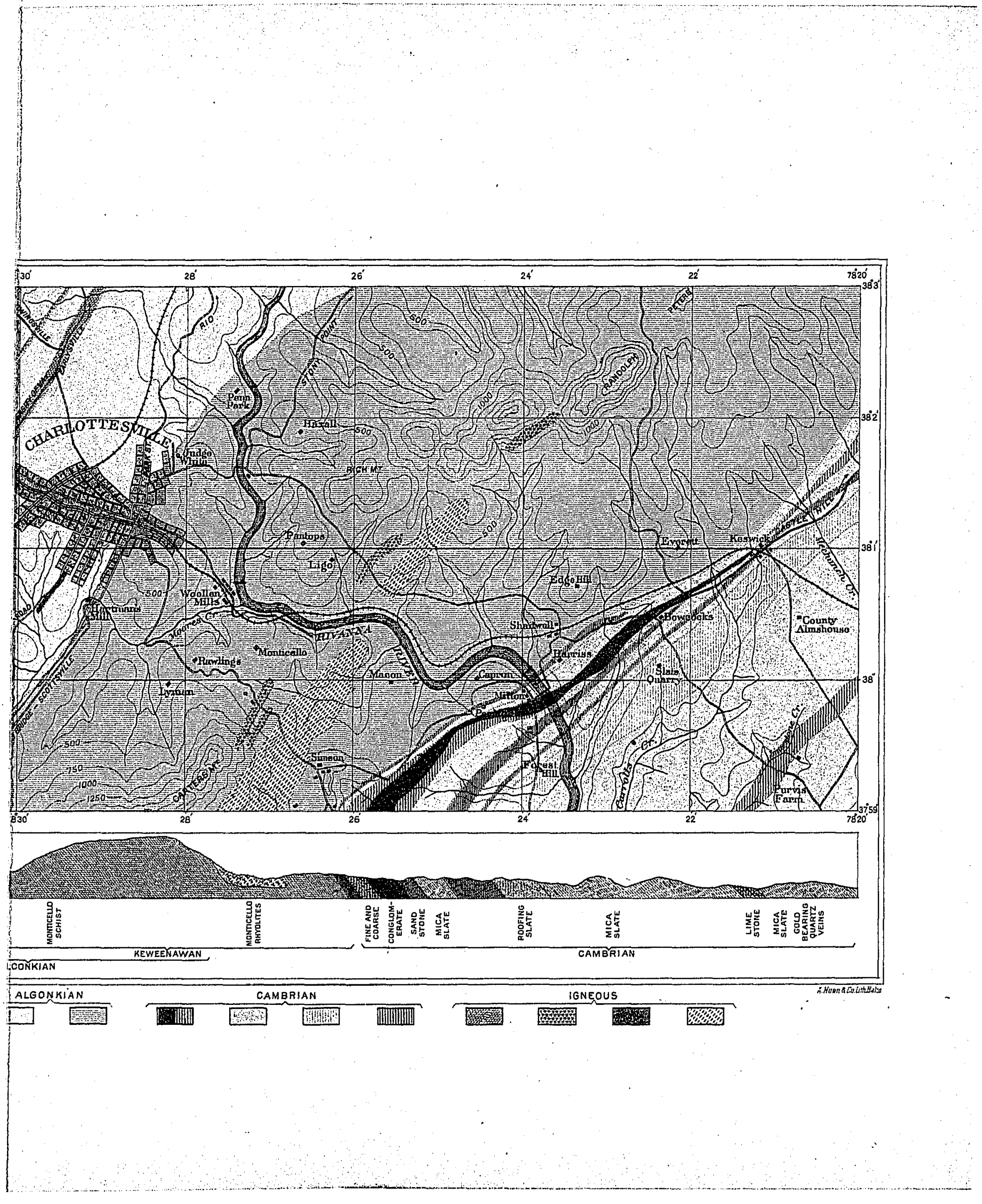


